\title{
PENGGUNAAN MODEL RECIPROCAL TEACHING UNTUK MENINGKATKAN HASIL BELAJAR SISWA PADA MATA PELAJARAN IPA KELAS V SD NEGERI I TOPA KOTA BAUBAU
}

\author{
Hijrawati Aswat ${ }^{1}$ Syamsurijal ${ }^{2}$ \\ Prodi Pendidikan Guru Sekolah Dasar, Fakultas Keguruan dan Ilmu Pendidikan \\ Universitas Muhammadiyah Buton, Jl. Betoambari No. 36 Baubau. \\ E-mail: Hijrawati_aswat@yahoo.co.id,zmbrhijal@gmail.com
}

\begin{abstract}
Abstrak
Penelitian ini bertujuan untuk mengetahui keefektifan pelaksanaan pembelajaran terbalik (Reciprocal Teaching) terhadap hasil belajar IPA siswa kelas V SD Negeri I Topa Kota Baubau. Jenis penelitian ini adalah Penelitian Tindakan Kelas yang terdiri dari dua siklus, masing-masing sikluas 3 kali pertemuan. Subjek dalam penelitian ini adalah siswa Kelas V SD Negeri I Topa Kota Baubau tahun ajaran 2018/2019 sebanyak 20 siswa. Instrumen yang digunakan terdiri dari lembar observasi guru dan siswa serta tes berupa essay untuk melihat hasil belajar IPA. Hasil penelitian menunjukkan bahwa: (i) Pelaksanaan pembelajaran dengan menggunakan model pembelajaran terbalik (Reciprocal Teaching) mengalami peningkatan di setiap pertemuan baik dari segi keterlaksanaan pembelajaran maupun aktivitas belajar siswa. (ii) Terdapat peningkatan hasil belajar IPA siswa dari siklus I ke siklus II dengan menggunakan model pembelajaran terbalik (Reciprocal Teaching) pada siswa Kelas V SD Negeri I Topa Kota Baubau.
\end{abstract}

Kata kunci: Model pembelajaran terbalik (Reciprocal Teaching), Hasil belajar IPA.

\begin{abstract}
This study aims to determine the effectiveness of the implementation of reverse learning (Reciprocal Teaching) on science learning outcomes of fifth grade students of SD Negeri I Topa, Baubau City. The type of this research is Class Action Research which consists of two cycles, each of which is 3 times. The subjects in this study were Class $V$ students of Baubau City Elementary School I Topa 2018/2019 as many as 20 students. The instrument used consisted of teacher and student observation sheets and tests in the form of essays to see the learning outcomes of science. The results showed that: (i) The implementation of learning using the reverse learning model (Reciprocal Teaching) experienced an increase in each meeting both in terms of the implementation of learning and student learning activities. (ii) There is an increase in science learning outcomes of students from cycle I to cycle II by using the reverse learning model (Reciprocal Teaching) in Class V students of SD Negeri I Topa, Baubau City.
\end{abstract}

Keywords: Inverted learning model (Reciprocal Teaching), Science learning outcomes. 


\section{SANG PENCERAH}

Volume 4, Nomor 2, Agustus 2018, Hlm. 12-20

Hijrawati Aswat, Syamsurijal.: Penggunaan Model Reciprocal Teaching ...

\section{Pendahuluan}

Era globalisasi saat ini pendidikan merupakan hal yang sangat penting dalam kemajuan suatu bangsa. Demekian pula dengan bangsa ini, dimana pemerintah sangat memperhatikan bidang pendidikan, terutama pendidikan dasar untuk membentuk karakter peserta didik. UndangUndang Nomor 20 tahun 2003 tentang sistem pendidikan nasional, dijelaskan bahwa Pendidikan Nasional berfungsi mengembangkan kemampuan dan membentuk watak serta peradaban bangsa yang bermartabat dalam rangka mencerdaskan kehidupan bangsa, bertujuan untuk berkembangnya potensi peserta didik agar menjadi manusia yang beriman dan bertakwa terhadap Tuhan Yang Maha Esa dan menjadi warga negara yang demokratis serta bertanggung jawab.

Berdasarkan fungsi pendidikan nasional di atas, maka peran guru menjadi kunci keberhasilan dalam misi pendidikan dan pembelajaran di sekolah selain bertanggung jawab untuk mengatur, mengarahkan dan mendorong siswa untuk mencari tahu tentang alam secara sistematis sehingga IPA bukan hanya penguasaan kumpulan pengetahuan yang berupa faktafakta, konsep-konsep atau prinsip-prinsip tetapi juga merupakan suatu proses penemuan. Pendidikan IPA diharapkan dapat menjadi wahana bagi peserta didik untuk mempelajari diri sendiri dan alam sekitar serta prospek pengembangan lebih lanjut dalam menerapkannya di dalam kehidupan sehari-hari. Di samping itu pengajaran bidang pendidikan IPA khusunya di SD dapat diartikan sebagai pengajaran yang mengenai konsep kealaman atau pendidikan yang menyentuh aspek alam beserta kejadian-kejadian yang ada di lingkungan sekitar dengan menghubungkan dengan kehidupan sehari-hari siswa, agar pembelajaran IPA lebih bermakna dan mudah dipahami. Melalui pembelajaran IPA siswa dilatih dan dihadapkan pada lingkungan alam beserta isinya, dengan harapan agar siswa mampu mengelola dan mampu menyesuaikan diri terhadap lingkungannya, beradaptasi dengan baik dan mampu menyelesaikan setiap masalahmasalah sosial yang dihadapinya ketika kelak berada di lingkungan masyarakat yang menjadi tantangan hidup dan mampu mengambil keputusan dalam menyelesaikan masalah tersebut. Menurut Sumaji, (1997: $31,35)$ IPA berupaya meningkatkan minat manusia agar mau meningkatkan kecerdasan dan pemahamannya tentang alam dan seisinya yang penuh dengan rahasia yang tak ada habis-habisnya. Mata pelajaran IPA di Sekolah Dasar merupakan salah satu program pembelajaran yang bertujuan agar siswa memahami/menguasai konsep-konsep IPA dan saling keterkaitannya, serta mampu menggunakan metode ilmiah untuk memecahkan masalahmasalah yang dihadapinya, sehingga lebih menyadari kebesaran dan kekuasaan penciptanya.

Tujuan pembelajaran IPA di Sekolah Dasar dapat mengembangkan kognitif, afektif, psikomotorik, kreativitas serta melatih siswa dalam berpikir kritis dalam memahami fenomena-fenomena yang terjadi di alam atau peristiwa-peristiwa yang terjadi di lingkungan sekitar sehingga proses pembelajaran IPA diperlukan kreatifitas yang tinggi dari seorang guru dalam mengelola kelasnya, salah satunya terampil dalam pemilihan model pembelajaran yang tepat, agar siswa ikut dilibatkan secara aktif dalam proses pembelajaran. dengan ini tujuan pembelajaran akan lebih mudah tersalurkan kepada siswa dan siswa akan lebih mudah memahami pembelajaran IPA. Siswa yang secara aktif dan secara langsung terlibat dalam proses pembelajaran dapat meningkatkan motivasi belajar siswa sehingga berdampak pada hasil belajar siswa yang meningkat. Guru dituntut untuk mengetahui, memahami, memilih, dan menerapkan model pembelajaran yang 


\section{SANG PENCERAH}

Volume 4, Nomor 2, Agustus 2018, Hlm. 12-20

\section{Hijrawati Aswat, Syamsurijal.: Penggunaan Model Reciprocal Teaching ...}

dinilai efektif, menarik, dan variatif sehingga dapat menciptakan suasana kelas yang kondusif dalam menunjang proses pembelajaran. Salah satunya dengan penggunaan model Reciprocal Teaching. Suyatno(2009:64) "reciprocal teaching merupa

kan model pembelajaran berdasarkan prinsip-prinsip pengajuan pertanyaan di mana ketrampilan-ketrampilan metakognitif diajarkan melalui pengajaran langsung dan pemodelan oleh guru".

Pembelajaranmenggunakan reciprocal $t$ eaching harus memperhatikan tiga hal yaitu siswa belajar mengingat, berfikir dan memotivasi diri. Model pembelajaran reciprocal teaching juga merupakan suatu prosedur pembelajaran yang mengacu kepada siswa untuk bekerja bersama dalam kelompok kecil dan saling membantu dalam proses belajar (Suratno, 2008: 152). Dalam model ini terdapat empat keterampilan dasar, yaitu menyusun pertanyaan, memprediksi jawaban, mengklarifikasi jawaban, dan membuat rangkuman. Kesimpulan dari beberapa pendapat diatas bahwa model reciprocal teaching merupakan model pembelajaran aktif yang melibatkan siswa dalam belajar mandiri dan siswa dilatih dalam ikut mengutarakan pendapatnya dihadapan teman kelasnya, dengan berperan sebagai seorang guru yang menjelaskan materi pelajaran yang diketahuinya. Berdasarkan deskripsi di atas, fokus penelitian ini adalah bagaimanakah Penggunaan Model Reciprocal Teaching Untuk Meningkatkan Hasil Belajar Siswa Pada Mata Pelajaran IPA Kelas V SD Negeri I Topa Kota Baubau?

Penelitian ini bertujuan untuk mengetajui efektivitas Penggunaan Model Reciprocal Teaching Untuk Meningkatkan Hasil Belajar Siswa Pada Mata Pelajaran IPA Kelas V SD Negeri I Topa Kota Baubau.

\section{Metode Penelitian}

\section{Jenis Penelitian}

Penelitian ini merupakan penelitian tindakan kelas (classroomaction research) yang dilakukan secara bersiklus. Penelitian Tindakan Kelas ini ada dua siklus, masingmasing siklus terdiri atas empat kegiatan, yaitu: a) Perencanaan (planning), b) Pelaksanaan tindakan (action), c) Observasi dan evaluasi (observation and evaluation), dan d) Refleksi (reflection).

\section{Setting dan Subjek Penelitian}

Penelitian ini dilaksanakan di SD Negeri I Topa Kota Baubau dengan menerapkan Penggunaan model pembelajaran Reciprocal Teaching pada pembelajaran Ilmu Pengetahuan Alam (IPA) Kelas V. Subjek penelitian ini adalah murid kelas $\mathrm{V}$ yang berjumlah 23 orang murid, yang terdiri dari 15 orang murid perempuan, 8 orang murid laki-laki, pada semester ganjil tahun ajaran 2018/2019.

\section{Teknik Pengumpulan Data}

Sumber data dalam penelitian ini adalah murid dan guru kelas V SD Negeri I Topa Kota Baubau. Jenis data yang digunakan dalam penelitian ini adalah data kuantitatif dan kualitatif. Menurut Sugiyono (2013:224), tehnik pengumpulan data merupakan langkah yang paling strategis dalam penelitian, karna tujuan utama dari penelitian adalah mendapatkan data. Data tersebut diperoleh dengan menggunakan tehnik Observasi dan Tes.

1. Observasi

Pengambilan data berupa informasi mengenai situasi belajar mengajar yang menyangkut aktivitas guru dan siswa dalam proses pembelajaran. Observasi dilakukan dengan menggunakan pedoman yang di dalamnya sudah tertera indikator - indikator yang akan diamati.

2. Tes

Pengambilan data berupa informasi mengenai penguasaan siswa terhadap 


\section{SANG PENCERAH}

Volume 4, Nomor 2, Agustus 2018, Hlm. 12-20

Hijrawati Aswat, Syamsurijal.: Penggunaan Model Reciprocal Teaching ...

pembelajaran IPA yang dilakukan dengan cara pemberian soal-soal. Tes ini dilakukan pada akhir setiap siklus/tindakan.

\section{Teknik Analisis Data}

Milles dan Huberman (dalam Aqib, 2008) mengatakan tehnik analisis data yang digunakan dalam penelitian adalah model alur, yaitu reduksi data, penyajian data, dan penarikan kesimpulan. Data yang diperoleh dari hasil observasi dan tes akan dianalisis bersama dengan observer. Data tersebut akan disaring atau diseleksi terlebih dahulu. Data yang dianggap penting dan keabsahannya tinggi akan disajikan. Sedangkan data yang tidak penting akan disimpan dan dijadikan arsip dengan pertimbangan mungkin suatu saat akan dibutuhkan. Data yang sudah diseleksi kemudian disajikan dan selanjutnya peneliti dan observermendiskusikan data tersebut untuk menarik suatu kesimpulan.

\section{Pembahasan}

\section{Deskripsi Data Hasil Penelitian}

Pada bagian ini dibahas hasil-hasil penelitian yang memperlihatkan peningkatan hasil belajar IPA melalui model pembelajaran reciprocal teaching bagi siswa kelas V SD Negeri I Topa Kota Baubau Penelitian ini dilakukan secara bertahap dan sistematis dengan melalui dua siklus. Hasil dan pembahasan yang diperoleh dari dua siklus pelaksanaan penelitian ini, dapat diuraikan sebagai berikut:

\section{Hasil Analisis Data Penelitian Persiklus}

\section{a. Tahap Perencanaan Siklus I}

Perencanaan yang dilakukan pada siklus I yaitu:

1) Peneliti beserta guru kelas menentukan standar kompetensi dan kompetensi dasar yang akan disampaikan kepada murid dengan menggunakan pembelajaran model Reciprocal Teaching.

2) Membuat rencana pembelajaran Reciprocal Teaching.

3) Membuat lembar kerja murid.

4) Membuat instrument yang akan digunakan dalam siklus I.

5) Merancang media pembelajaran yang akan diajarkan

6) Memberikan evaluasi akhir siklus I.

7) Membuat lembar observasi siswa dan guru.

\section{b. Tahap Pelaksanaan Siklus I}

Pelaksanaan kegiatan dilakukan berdasarkan uraian berikut :

1) Melaksanakan proses pembelajaran sesuai dengan RPP yang telah dibuat pada tahap perencanaan

2) Peneliti mengamati secara totalitas jalannya pembelajaran.

3) Guru melaksanakan proses belajar mengajar yang telah direncanakan sebelumnya yaitu dengan menggunakan model pembelajaran Reciprocal Teaching dalam pembelajaran IPA pada murid kelas $\mathrm{V}$ SD Negeri I Topa Kota Baubau.

4) Memberikan evaluasi siklus I untuk menegetahui kemampuan dan ketuntasan murid dalam belajar.

Siklus I dilaksanakan sebanyak dua kali pertemuan untuk proses belajar mengajar dengan alokasi waktu $3 \times 35$ menit disetiap pertemuan yang terdiri dari kegiatan awal 10 menit, kegiatan inti 80 menit, kegiatan akhir 15 menit. Materi pelajaran yang dibahas pokok bahasan tema 2, sub tema 1 Cara tubuh mengelola udara bersih dengan model pembelajaran Reciprocal Teaching. 


\section{SANG PENCERAH}

Volume 4, Nomor 2, Agustus 2018, Hlm. 12-20

Hijrawati Aswat, Syamsurijal.: Penggunaan Model Reciprocal Teaching ...

\section{c. Hasil Observasi Siklus I}

1) Aktivitas belajar siswa

Hasil observasi untuk mengetahui perubahan sikap murid dalam pembelajaran selama siklus pertama dapat dilihat pada tabel berikut:

Tabel 1 Perolehan Skor Aktivitas Siswa

\begin{tabular}{cccc}
\hline Tahap Pengamatan & \multicolumn{3}{c}{ Pertemuan ke } \\
\cline { 2 - 4 } Murid & I & II & III \\
\hline Kegiatan awal & 16 & 16 & Evaluasi \\
Kegiatan inti & 24 & 28 & \\
Kegiatan akhir & 14 & 15 & \\
\hline Persentase (\%) & $\mathbf{5 4}$ & $\mathbf{5 9}$ & \\
\hline
\end{tabular}

keaktifan siswa kelas $\mathrm{V}$ SD Negeri I Topa Kota Baubau, secara keseluruhan kegiatan siswa selama proses belajar mengajar mulai dari kegiatan awal hingga kegiatan akhir berada pada kategori cukup , pada pertemuan ke-1 dan ke-2 mengalami peningkatan aktivitas belajar pada hari pertama ke hari kedua menjadi 59\% dari skor $100 \%$.

2) Kegiatan Megajar Guru

Kegiatan mengajar guru pada siklus I diperoleh berdasarkan lembar observasi kegiatan guru, pada pertemuan pertama dari 19 kegiatan, ada 5 kegiatan yang tidak dilakukan dengan baik oleh guru, sehingga memperoleh 56 total dari 95 skor (58,95\%). Pada pertemuan ke-2 diperoleh hasil observasi guru ada 2 kegiatan yang tidak dilakukan, dengan perolehan 70 total dari 95 skor (73,68\%). Ada peningkatan aktivitas guru dari hari pertama ke hari ke-2 sebesar $14,73 \%$.
3) Hasil evaluasi siklus I

Setelah selesai penyajian materi suatu kompetensi dasar pada siklus I dilaksanakan tes akhir. Pada siklus ini dilaksanakan tes hasil belajar yang berbentuk essay sebanyak 10 butir soal setelah selesai penyajian beberapa sub pokok bahasan. Apabila skor hasil belajar siswa dikelompokkan ke dalam lima kategori maka diperoleh distribusi frekuensi yang ditunjukkan pada tabel berikut ini:

Tabel 2 Rekapitulasi Hasil Tes Tertulis (Formatif) Siswa Pada Siklus I

\begin{tabular}{|c|c|c|c|}
\hline Skor & Kategori & Frekuensi & $\begin{array}{c}\text { Presentase } \\
(\%)\end{array}$ \\
\hline $0-34$ & Kurang & 0 & 0 \\
\hline $35-54$ & Rendah & 4 & 20 \\
\hline $55-69$ & Sedang & 3 & 15 \\
\hline $70-84$ & Tinggi & 10 & 50 \\
\hline $85-100$ & Sangat tinggi & 3 & 15 \\
\hline \multicolumn{2}{|r|}{ Jumlah } & 20 & 100 \\
\hline $0-69$ & Tidak Tuntas & 7 & $35 \%$ \\
\hline $70-100$ & Tuntas & 13 & $65 \%$ \\
\hline
\end{tabular}

Berdasarkan tabel diatas, dideskripsikan bahwa hasil belajar IPA siswa kelas V SD Negeri I Topa Kota Baubau setelah dilakukan tindakan pada siklus I mengacu pada standar keberhasilan dalam penelitian berada dalam kategori "cukup" dengan tingkat penguasaan $65 \%$ dari jumlah siswa mendapat nilai $\geq 7,0$, sehingga peneliti perlu melakukan tindakan selanjutnya pada siklus II.

\section{d. Refleksi Siklus I}

Dalam pelaksanaan kegiatan belajar mengajar (KBM) diperoleh informasi dari hasil pengamatan sebagai berikut:

1) Siswa masih kurang bersemangat sehingga peneliti berusaha bagaimana dapat menarik perhatian siswa dalam mengikuti proses belajar mengajar. 


\section{SANG PENCERAH}

Volume 4, Nomor 2, Agustus 2018, Hlm. 12-20

Hijrawati Aswat, Syamsurijal.: Penggunaan Model Reciprocal Teaching ...

2) Siswa belum terbiasa dengan kondisi belajar dengan menggunakan pembelajaran model Reciprocal Teaching. Walaupun mereka merasa senang dan antusias dalam proses belajar.

3) Setelah pelaksanaan evaluasi pada siklus pertama sudah mencapai rata-rata $72,45 \%$ dari skor ideal 100, namun belum terlalu memuaskan dan sesuai dengan standar keberhasilan penelitian yaitu $85 \%$ dari jumlah siswa mendapat nilai $\geq 70$ maka pembelajaran dapat dikatakan berhasil.

4) Masih ada beberapa siswa yang belum bisa memerankan model sebagai seorang guru yang memaparkan materi didepan kelas.

\section{Paparan Data Siklus II}

a. Tahap Perencanaan Siklus II

Seperti pada siklus pertama, siklus kedua ini terdiri dari perencanaan, pelaksanaan, obsevasi, dan refleksi. Pada tahap ini peneliti mempersiapkan perangkat pembelajaran yang terdiri dari rencana pelaksanaan pembelajaran 2, LKS 2 , soal tes formatif, dan alat-alat pengajaran yang mendukung. Perencanaan pada siklus kedua berdasarkan replaning siklus pertama, yaitu (1) Lebih memotivasi lagi kepada murid agar lebih aktif dan fokus dalam pelaksanaan proses pembelajaran;

Membimbing murid yang mengalami kesulitan dan belum memahami proses pelaksanaan pembelajaran; (3) Memberi pengakuan atau penghargaan bagi murid yang dapat memaparkan materi pelajaran; dan (4) Menyampaikan materi pembelajaran secara jelas dan mudah dipahami oleh murid.

\section{b. Tahap Pelaksanaan Siklus II}

$$
\text { pada rencana pelajaran dengan }
$$

memperhatikan revisi pada siklus I, sehingga kesalahan atau kekurangan pada siklus I tidak terulang lagi pada siklus II. Pengamatan (observasi) dilaksanakan bersamaan dengan pelaksanaan belajar mengajar. Alokasi waktu yang digunakan $3 \times 35$ menit yang berlangsung selama 105 menit. Diikuti oleh 20 jumlah siswa.

\section{c. Hasil Observasi Siklus II}

1) Kegiatan Mengajar Guru

Aktivitas guru berdasarkan hasil observasi yang dilakukan pada siklus II, sudah ada beberapa perbaikan aktivitas guru hasil dari refleksi pada siklus pertama, semua aktivitas terlaksana dari 19 aktivitas, meskipun ada beberapa yang belum maksimal, dengan perolehan 82 dari 95 skor maksimal $(86,32, \%)$ dengan kualifikasi baik.

2) Kegiatan Siswa

Hasil observasi pada siklus II untuk mengetahui perubahan sikap murid dalam pembelajaran selama siklus kedua dapat dilihat pada tabel berikut:

Tabel 3 Perolehan Skor Aktivitas Siswa

\begin{tabular}{cccc}
\hline Tahap Pengamatan & \multicolumn{3}{c}{ Pertemuan ke } \\
\cline { 2 - 4 } Murid & I & II & III \\
\hline Kegiatan awal & 22 & 23 & Evaluasi \\
Kegiatan inti & 36 & 40 & Siklus II \\
Kegiatan akhir & 26 & 27 & \\
\hline Persentase (\%) & 84 & 90 & \\
\hline
\end{tabular}

Berdasarkan tabel di atas dapat diperoleh bahwa keaktifan siswa kelas V SD Negeri I Topa Kota Baubau, secara keseluruhan kegiatan siswa selama proses belajar mengajar mulai dari kegiatan awal hingga kegiatan akhir kegiatan siswa dalam proses pembelajaran terus meningkat baik dari siklus I. 


\section{SANG PENCERAH}

Volume 4, Nomor 2, Agustus 2018, Hlm. 12-20

Hijrawati Aswat, Syamsurijal.: Penggunaan Model Reciprocal Teaching ...

3) Hasil Evaluasi Siklus II

Pada akhir proses belajar mengajar siswa diberi tes formatif II dengan tujuan untuk mengetahui tingkat keberhasilan siswa dalam proses belajar mengajar yang telah dilakukan. Instrumen yang digunakan adalah tes formatif II. Apabila skor hasil belajar siswa dikelompokkan ke dalam lima kategori maka diperoleh distribusi frekuensi yang ditunjukkan pada tabel berikut ini:

Tabel 4 Rekapitulasi Hasil Tes (Formatif) Siswa pada Siklus II

\begin{tabular}{lccc}
\hline Skor & Kategori & Frekuensi & $\begin{array}{c}\text { Presentase } \\
\mathbf{( \% )}\end{array}$ \\
\hline $0-34$ & Kurang & 0 & 0 \\
$35-54$ & Rendah & 0 & 0 \\
$55-69$ & Sedang & 3 & 15 \\
$70-84$ & Tinggi & 10 & 50 \\
$85-$ & Sangat & 7 & 35 \\
100 & tinggi & & \\
\hline Jumlah & & $\mathbf{2 0}$ & $\mathbf{1 0 0}$ \\
\hline Skot Tertinggi & 100 & $78,06 \%$ \\
Skor Terendah & 50 & $85 \%$ \\
Nilai Rata-Rata & 78,06 & $15 \%$ \\
Tuntas & 17 & \\
Tidak Tuntas & 3 & \\
\hline
\end{tabular}

Hal ini menunjukkan bahwa telah terjadi peningkatan hasil belajar IPA siswa kelas V SD Negeri I Topa Kota Baubau melalui model pembelajaran Reciprocal Teaching. Tabel di atas juga menunjukkan bahwa $85 \%$ murid mempunyai tingkat penguasaan materi 70 keatas artinya bahwa hasil belajar murid dapat dikatakan tuntas secara klasikal. Dengan demikian diperoleh keterangan bahwa terjadi peningkatan hasil belajar IPA Siswa kelas V SD Negeri I Topa Kota Baubau melalui model pembelajaran Reciprocal Teaching.

\section{d. Refleksi Siklus II}

Pada tahap ini akan dikaji apa yang telah terlaksana dengan baik maupun yang masih kurang baik dalam proses belajar mengajar dengan penerapan model pembelajaran Reciprocal Teaching. Dari data-data yang telah diperoleh dapat diuraikan sebagai berukut (1) Selama proses belajar mengajar guru telah melaksanakan semua pembelajaran dengan baik. Meskipun ada beberapa aspek yang belum sempurna, tetapi persentase pelaksanaanya untuk masingmasing aspek cukup besar; (2) Berdasarkan data hasil pengamatan diketahui bahwa siswa aktif selama proses pembelajaran berlangsung; (3) Kekurangan pada siklus-siklus sebelumnya sudah mengalami perbaikan dan peningkatan sehingga menjadi lebih baik; (4) Hasil belajar siswa pada siklus II mencapai ketuntasan.

Pembahasan hasil penelitian tentang penggunaan model pembelajaran reciprocal teaching untuk meningkatkan hasil belajar siswa pada mata pelajaran IPA kelas V SD Negeri I Topa Kota Baubau. Hasil penelitian akan dipaparkan berdasarkan hasil analisis data melalui hasil observasi kegiatan belajar siswa ditemukan bahwa terjadi peningkatan aktivitas belajar siswa dari sikluas I ke siklus II begitupun hasil belajar siswa.

\section{Ketuntasan Hasil Belajar Siswa}

Melalui hasil penelitian ini menunjukkan bahwa model pembelajaran Reciprocal Teaching memiliki dampak positif dalam meningkatkan hasil belajar siswa. hasil analisis deskriptif kuantitatif skor hasil belajar IPA Siswa kelas V SD Negeri I Topa Kota Baubau pada siklus I menunjukkan bahwa skor rata-rata setelah pelaksanaan siklus I adalah $72,45 \%$ dari skor ideal 100, dengan skor tertinggi 98 dan skor terendah 45 . Siswa yang masuk dalam kategori tuntas terdapat 13 orang siswa yang berada pada kategori tinggi 10 orang siswa dan 


\section{SANG PENCERAH}

Volume 4, Nomor 2, Agustus 2018, Hlm. 12-20

Hijrawati Aswat, Syamsurijal.: Penggunaan Model Reciprocal Teaching ...

kategori sangat tinggi 3 orang siswa. Sedangkan siswa yang tidak tuntas terdapat 7 orang siswa, terdapat 4 orang siswa yang berada pada kategori rendah dan 3 orang siswa yang berada pada kategori sedang. Hal ini menunjukkan perubahan hasil belajar yang baik dengan diterapkannya model pembelajaran reciprocal teaching, dibandingkan hasil belajar siswa sebelum diterapkan model pembelajaran. Begitupun dengan aktivitas belajar siswa yang diperoleh berdasarkan hasil observasi siswa menunjukkan keaktifan siswa secara keseluruhan kegiatan siswa selama proses belajar mengajar mulai dari kegiatan awal hingga kegiatan akhir meningkat baik.

Pada siklus II dideskripsikan bahwa hasil belajar IPA siswa kelas V SD Negeri I Topa Kota Baubau setelah dilakukan tindakan pada siklus I sebesar 72,45 dan pada siklus II terlihat bahwa skor rata-rata hasil belajar IPA siswa sebesar 78, 6 dan berada pada kategori tinggi. Siswa yang tuntas hasil belajarnya ada 17 siswa sedangkan yang tidak tuntas, yang mendaptkan nilai dibawah nilai KKM hanya ada 3 siswa. Berdasarkan hasil observasi siswa pada siklus II pertemuan pertama mencapai $84 \%$, pada pertemuan kedua mencapai $90 \%$, hal inimenunjukkan bahwa kegiatan siswa dalam proses pembelajaran terus meningkat baik dari siklus I. Hasil evaluasi penguasaan siswa terhadap materi pelajaran pada siklus kedua mengalami peningkatan yakni nilai nilai ratarata diperoleh pada siklus I adalah $72,45 \%$ dan pada siklus II meningkat menjadi $78,06 \%$. Jadi antara siklus I dan siklus II mengalami peningkatan sebesar 5,61\%.

Hal ini dapat dilihat dari semakin mantapnya pemahaman siswa terhadap materi yang disampaikan oleh guru (ketuntasan belajar meningkat dari siklus I dan II) yaitu masing-masing $72,45 \%$ dan $78,06 \%$. Pada siklus II ketuntasan belajar siswa secara klasikal telah tercapai yaitu $85 \%$ siswa tuntas hasil belajarnya.
1. Kemampuan Guru dalam Mengelola Pembelajaran

Berdasarkan analisis data, diperoleh aktivitas siswa dalam proses pembelajaran dengan model Reciprocal Teaching dalam setiap siklus mengalami peningkatan. Hal ini berdampak positif terhadap hasil belajar siswa yaitu dapat ditunjukkan dengan meningkatnya nilai rata-rata siswa pada setiap siklus yang terus mengalami peningkatan.

2. Aktivitas Guru dan Siswa Dalam Pembelajaran

Berdasarkan analisis data, diperoleh aktivitas siswa dalam proses pembelajaran IPA pada pokok bahasan tema 2, sub tema 1 Cara tubuh mengelola udara bersih dengan model pembelajaran Reciprocal Teaching yang paling dominan adalah mendengarkan/memperhatikan penjelasan guru, melakukan pemodelan dengan baik dan diskusi antar siswa/antara siswa dengan guru. Jadi dapat dikatakan bahwa aktivitas siswa dapat dikategorikn aktif.

Sedangkan untuk aktivitas guru selama pembelajaran telah melaksanakan langkah-langkah belajar aktif dengan baik. Hal ini terlihat dari aktivitas guru yang muncul diantaranya aktivitas membimbing dan mengamati siswa dalam mengerjakan kegiatan LKS/menemukan konsep, menjelaskan materi yang tidak dimengerti, memberi umpan balik/evaluasi/tanya jawab dimana presentasi untuk aktivitas di atas cukup besar. Dari peningkatan hasil belajar siswa dan aktivitas belajar siswa tersebut dapat dikatakan bahwa penerapan model pembelajaran reciprocal teaching dapat meningkatkan hasil belajar siswa.

\section{Simpulan}

Simpulan penelitian ini bahwa (1) Pembelajaran dengan model Reciprocal Teaching memiliki dampak positif dalam meningkatkan hasil belajar siswa yang ditandai dengan peningkatan ketuntasan 


\section{SANG PENCERAH}

Volume 4, Nomor 2, Agustus 2018, Hlm. 12-20

\section{Hijrawati Aswat, Syamsurijal.: Penggunaan Model Reciprocal Teaching ...}

belajar siswa dalam setiap siklus; dan (2) Penerapan model pembelajaran Reciprocal Teaching mempunyai pengaruh positif, yaitu dapat meningkatkan keaktifan siswa dalam proses belajar mengajar yang ditunjukkan dengan keterlibatan siswa dalam proses tanya jawab dan memaparkan materi pelajaran didepan kelas.

\section{Daftar Pustaka}

Arikunto Suharsimi dkk. 2012. Penelitian Tindakan Kelas. Jakarta: Bumi Aksara.

Depdikbud. 1990. Kamus Besar Bahasa Indonesia. Jakarta: Balai Pustaka.

Depdiknas. 2003. Penelitian Tindakan Kelas. Bahan Ajar Pembekalan Guru Bantu.

Husdarta. 2013. Belajar dan Pembelajaran. Bandung: Alfabeta.

Mulyasa. 2010. Menjadi Guru Profesional (Menciptakan Pembelajaran Kreatif Dan Menyenangkan). Bandung: Rosda.

Nur, M. dan Wikandari, P.R. 2000. Pengajaran Berpusat Kepada Siswa Dan Pendekatan Konstruktivis Dalam Pengajaran. Surabaya: Universitas Negeri Surabaya.

Slameto. 2012. BelajarEFaktor-Faktor yang Mempengaruhinya. Jakarta: Rineka Cipta.

Sutarno, Nono. 2008. Materi Dan Pembelajaran IPA SD. Jakarta: Universitas Terbuka.

Sulandari \& Sri Riyanti. 2005. Pengembangan Model Pembelajaran Terbalik (Reciprocal Teaching) pada Mata Kuliah Perancangan Bahandan Tebal Perkerasan dalam Upaya Meningkatkan Kualitas Belajar Mahasiswa Teknik Sipil di Fakultas Teknik, Universitas Tanjungpura.

Sugiyono. 2013. Metode Penelitian Kuantiatif, Kualitatif dan RED. Bandung: Alfabeta.

Suyatno, 2009. Pembelajaran Inovatif. Sidoarjo: Masmedia buana Pustaka.

Trianto 2007.Model-model Pembelajaran Inovatif Berorientasi Konstruktivistik. Jakarta: prestasipustaka.

2010. Mendesain Model PembelajaranInovatif-Progresif. Jakarta: Kencana.

2011. Mengembangkan Model Pembelajaran Tematik. Jakarta: Prestasi Pustaka Raya.

Wiludjeng, I. 1999. Penerapan Pendekatan Reciprocal Teaching dalam Pembelajaran Fisika SMU Pokok Bahasan Tektonik Lempeng. Tesis Magister Pendidikan tidak dipublikasikan. Surabaya: PPs Universitas Negeri Surabaya.

Widayati Ani \& Pratiwi Inung. 2012. Pembelajaran Akuntansi melalui Reciprocal Teaching untuk Meningkatkan Penguasaan Konsep dan Kemandirian Belajar dalam Materi Mengelola Administrasi Surat Berharga Jangka Pendek Siswa Kelas X Akuntansi 1 SMK Negeri 7 Yogyakarta Tahun Pelajaran 2011/2012. Jurnal Pendidikan Akuntansi Indonesia(online). Vol.X, No. 2, Tahun 2012. 